Review

\title{
Fusarium, an Entomopathogen-A Myth or Reality?
}

\section{Lav Sharma *(1) and Guilhermina Marques}

CITAB - Centre for the Research and Technology of Agro-Environmental and Biological Sciences, University of Trás-os-Montes and Alto Douro (UTAD), Vila Real 5000-801, Portugal; gmarques@utad.pt

* Correspondence: 1sharma@utad.pt; Tel.: +351-25-9350-2472

Received: 8 October 2018; Accepted: 26 November 2018; Published: 28 November 2018

check for updates

\begin{abstract}
The Fusarium species has diverse ecological functions ranging from saprophytes, endophytes, and animal and plant pathogens. Occasionally, they are isolated from dead and alive insects. However, research on fusaria-insect associations is very limited as fusaria are generalized as opportunistic insect-pathogens. Additionally, their phytopathogenicity raises concerns in their use as commercial biopesticides. Insect biocontrol potential of Fusarium is favored by their excellent soil survivability as saprophytes, and sometimes, insect-pathogenic strains do not exhibit phytopathogenicity. In addition, a small group of fusaria, those belonging to the Fusarium solani species complex, act as insect mutualists assisting in host growth and fecundity. In this review, we summarize mutualism and pathogenicity among fusaria and insects. Furthermore, we assert on Fusarium entomopathogenicity by analyzing previous studies clearly demonstrating their natural insect-pathogenicity in fields, and their presence in soils. We also review the presence and/or production of a well-known insecticidal metabolite beauvericin by different Fusarium species. Lastly, some proof-of-concept studies are also summarized, which demonstrate the histological as well as immunological changes that a larva undergoes during Fusarium oxysporum pathogenesis. These reports highlight the insecticidal properties of some Fusarium spp., and emphasize the need of robust techniques, which can distinguish phytopathogenic, mutualistic and entomopathogenic fusaria.
\end{abstract}

Keywords: beauvericin; entomopathogenic fungi; Fusarium oxysporum; Fusarium solani; insect biological control

\section{Introduction}

Fusarium (Link ex Grey) species are hyaline filamentous fungi, which are ubiquitous with cosmopolitan distribution. They belong to the family Nectriaceae of the order Hypocreales within the fungal phylum Ascomycota. They can be found in air, water, plants, insects, soils and organic substrates. Based on host-associations, morphology and molecular characterizations, it is estimated that the genus Fusarium is comprised of at least 200 species recognized in 22 species complexes [1]. They are among the most destructive plant pathogenic and mycotoxigenic fungi. Their relevance in the agricultural industry is immense resulting in multi-billion dollar losses due to reduced crop yield. Moreover, they are reported frequently from infections in humans and animals. Some significant plant diseases caused include the Fusarium head blight in cereals, root rot in pea, ear rot in maize, sudden death syndrome in soybeans, and vascular wilts in numerous agricultural crops [2]. The prominence of Fusarium infections in plants can be estimated by the fact that two Fusarium spp., Fusarium graminearum Schwabe (teleomorph: Gibberella zeae (Schwein.) Petch) and Fusarium oxysporum Schlechtendahl are among the top five fungal pathogens of plants [3]. In animals, species such as F. oxysporum can cause infections in immunodepressed mice [4]. In humans, they cause infections collectively termed as fusariosis, which can be superficial such as keratitis or onychomycosis; locally invasive such as cellulitis, sinusitis or intertrigo; or deep or disseminated infections commonly occurring in severely 
immune-compromised patients [5]. Approximately $70 \%$ of Fusarium infections in humans are caused by F. oxysporum and Fusarium solani (Mart.) Sacc., the latter being more pathogenic and accounting for $50 \%$ of the infections [6]. Another species like Fusarium moniliforme Sheldon (Fusarium verticillioides (Sacc.) Nirenberg, or Fusarium fujikuroi Nirenberg; teleomorph: Gibberella fujikuroi (Sawada) Wollenw.) is relatively less prevalent, and accounts for $10 \%$ of human infections. Fusarium spp. causing superficial localized infections in humans as well as those which are phytopathogenic, were found pathogenic to insects, such as Galleria mellonella Linnaeus (Pyralidae: Lepidoptera). Both clinical and environmental strains of Fusarium spp. such as F. oxysporum and F. solani caused $100 \%$ of the mortalities of the insect larvae $[7,8]$. Moreover, the administration of anti-fungal agents like amphotericin $B$, which are effective against clinical Fusarium strains, also increased the survivability of the Fusarium infected larvae [8]. Such reports highlight the trans-kingdom pathogenicity of the Fusarium species.

Associations of fusaria with insects have been reported regularly during the last century. Wollenweber and Reinking reported 15 Fusarium isolates from insects [9]. Gordon collected approximately 9000 Fusarium isolates from the year 1932 onwards [10]. His isolates from the insects and other fungi together accounted for less than $1 \%$, and those insect-associated or "insecticolous fusaria" belonged to 12 taxa and were collected from 14 insect species [10]. Li reported four Fusarium spp. from the insects-pest of rice in China [11]. Feng-Yan and Quing-Tao reported 180 Fusarium isolates from approximately 150 dead or diseased insects including spiders [12]. Insect orders such as Lepidoptera, Coleoptera, Homoptera, Hymenoptera and Araneida were found infected by fusaria [12]. Several studies reporting pathogenicity of Fusarium spp., either in laboratory or on-field natural mycoses, against different insect orders were reported during the three decades, between 1950 to 1980 (reviewed in [13]). Similar observations on the entomopathogenicity of fusaria were reported by Cladon and Grove [14].

Teetor-Barsch and Roberts suggested that using entomopathogenic fusaria could be advantageous in insect biological control, as some insect-pathogenic strains (a) demonstrate high host specificity; (b) can be easily grown in a laboratory; (c) do not damage plants; and (d) survive better as saprophytes in soils [13]. Nonetheless, studies in this area never achieved the required focus as Fusarium is a renowned plant pathogen, and using it as an insect biological control agent may lead to the release of phytopathogens into agroecosystems. O'Donnell et al. argued that Fusarium spp. might be used in insect biocontrol if entomopathogenic fusaria could be distinguished from phytopathogenic strains using genetic markers [15]. Insecticolous fusaria can be found in association with insects, either as a symbiont, opportunistic pathogen, saprophyte-eating decaying body, or as an entomopathogen. Here we briefly discuss studies, which focus on insect-Fusarium mutualism, and argue the entomopathogenicity of Fusarium, in detail.

\section{Insect-Fusarium Mutualistic Association}

In the past, some Fusarium spp. such as Fusarium javanicum Koord., F. moniliforme, F. solani, Fusarium roseum Link and F. oxysporum were reviewed for their non-pathogenic associations with many beetles and other insects [13]. Ambrosia beetles (Scolytinae, Curculionidae: Coleoptera) vector several fungal plant pathogens, which live inside the hosts as mutualists. Euwallacea Hopkins spp. are fungus farming beetles which cultivate mutualist fusaria. The majority of these beetles do not cause harm to living plants but instead attack decaying or recently killed trees. However, some of them colonize living tress and, along with Fusarium spp., can cause disease such as Fusarium canker or Fusarium dieback [16]. The fusaria belonging to ambrosia beetles generally belong to the Fusarium solani species complex (FSSC). Overall, FSSC includes more than 60 species and at least 12 of them belong to the Fusarium ambrosia clade, although 10 of these species have not been described yet. These insect-mutualist fusaria have adapted themselves for symbiosis, as their morphology is different than the free-living fusaria [17]. It was thought that the Euwallacea-Fusarium association was highly specific, but phylogenetic studies have demonstrated that this mutualism has experienced multiple symbionts shifts during the course of evolution [18]. 
Ambrosia beetles harbor these fungi within their special external structures known as "mycangia". These beetles need these Fusarium spp. to digest lignocellulose and synthesize nutrients, such as ergosterols, which are required for pupation. There might be other roles of mutualist fusaria, however, it has been noted that, overall, the presence of fungi helps with insect growth and fecundity [19]. Occasionally, members of the FSSC have also been found associated with other beetles, such as the Asian longhorned beetles Anoplophora glabripennis Motschulsky (Coleoptera: Cerambycidae) [19]. Scully et al. performed a proteomic analysis of a F. solani isolate obtained from the gut of $A$. galbripennis grown on woody tissue, and found 400 expressed proteins, which are needed for plant cell wall degradation and digestion, and to recycle nitrogenous waste during periods of nutrient limitation [19]. These proteins encompassed several cutinases, pectate lyases, lipases, esterases, polysaccharide deacetylases, ureases, glycosyl hydrolases, laccases, peroxidases, and enzymes needed for hydrogen peroxide production, probably for lignin depolymerization [19].

\section{Fusarium as an Entomopathogen}

\subsection{Isolation Studies Claiming Fusarium Entomopathogenicity}

Hajek and Goettel suggested that the insect host range of an entomopathogen in a controlled laboratory environment is its "physiological host range". Another term, i.e., "ecological host range" of an entomopathogen is the range of the insect species which can be infected in field conditions [20]. There have been some studies in the past that suggest the entomopathogenic potential of fusaria in a laboratory setting [21,22]. However, caged laboratory conditions provide an additional benefit to the pathogen, and it is not a surprise that the physiological host range is generally higher than the ecological host range. Therefore, to reduce any bias and to be sure about the entomopathogenicity of Fusarium spp., we undertook a stringent approach as described below, and reviewed only those studies where at least the species names of obtained fusaria were mentioned. In this section, the focus was on the investigations undertaken after the review by Teetor-Barsch and Roberts [13].

- Only those studies were considered where fusaria were found on the insects in field conditions, not on stored grains, and where Koch's postulates for pathogenicity were confirmed.

- Moreover, those studies where fusaria were isolated from soils using an insect-bait were also considered, if Koch's postulates were subsequently confirmed for the isolated strains.

\subsubsection{Isolations from Soils using the Insect-Bait Method and subsequent Koch's Postulates Confirmation}

Soil baiting using an infection sensitive insect such as the larvae of G. mellonella is a widely known technique for the isolation of entomopathogenic fungi from soils [23-25]. Generally this methodology is used to report entomopathogens such as Beauveria Vuillemin (Hypocreales: Cordycipitaceae) and Metarhizium Sorokin (Hypocreales: Clavicipitaceae). However, a few studies chose to mention the isolation of Fusarium spp. using this technique [25-27]. A total of seven Fusarium spp. exhibiting entomopathogenicity, were isolated from the soils, Fusarium avenaceum (Fr.) Sacc., Fusarium heterosporum Nees, F. moniliforme, F. oxysporum, Fusarium semitectum Berk. \& Ravenel., F. solani and Fusarium redolens Wollenw. (Table 1).

\subsubsection{Natural On-Field Insect Mycoses and Subsequent Koch's Postulates Confirmation}

We carefully selected studies which claimed the entomopathogenicity of fusaria obtained from field infected insect cadavers. The criteria undertaken has already been mentioned earlier. A total of eight studies could meet this criteria and ten Fusarium spp. were found exhibiting natural entomopathogenicity, Fusarium acuminatum Ellis \& Everh., F. avenaceum, Fusarium culmorum (Wm. G. Sm) Sacc., Fusarium equiseti (Corda) Sacc., Fusarium merismoides Corda, F. oxysporum, Fusarium proliferatum (Matsush.) Nirenberg ex Gerlach \& Nirenberg, Fusarium pseudograminearum Aoki \& O'Donnell, F. solani and F. verticillioides (Table 2). 
Table 1. Soil isolations of Fusarium spp. using Galleria-bait method and subsequent pathogenicity confirmation.

\begin{tabular}{|c|c|c|c|c|c|c|}
\hline Fusarium Species & $\begin{array}{l}\text { Isolation } \\
\text { Numbers and } \\
\text { Respective } \\
\text { Frequencies }\end{array}$ & $\begin{array}{c}\text { Koch's } \\
\text { Postulate } \\
\text { Confirmed (A *) }\end{array}$ & $\begin{array}{c}\text { Percentage (\%) } \\
\text { Mortality } \\
\text { During A* }\end{array}$ & Plantation & Country & Reference \\
\hline F. avenaceum & $11(2.91 \%)$ & yes & $0-26.7$ & Forests & China & [27] \\
\hline F. heterosporum & $1(1.4 \%)$ & yes & 18 & Citrus orchard & Palestine & [26] \\
\hline \multirow{2}{*}{ F. oxysporum } & $35(9.3 \%)$ & yes & $0-93.3$ & Forests & China & [27] \\
\hline & $2(2.9 \%)$ & yes & $30-33$ & $\begin{array}{c}\text { Vegetable fields } \\
\text { and citrus orchard }\end{array}$ & Palestine & [26] \\
\hline \multirow[t]{2}{*}{ F. solani } & $5(7.14 \%)$ & yes & $28-44$ & $\begin{array}{l}\text { Vegetable fields } \\
\text { and citrus orchard }\end{array}$ & Palestine & [26] \\
\hline & $18(4.8 \%)$ & yes & $0-86.7$ & Forests & China & [27] \\
\hline F. redolens & $1(0.26 \%)$ & yes & 26.7 & Forests & China & [27] \\
\hline F. semitectum & $7(10 \%)$ & yes & $16-33$ & Vegetable fields & Palestine & [26] \\
\hline $\begin{array}{l}\text { F. verticillioides } \\
\text { (=F. moniliforme } \\
\text { or F. fujikuroi; } \\
\text { teleomorph: } \\
\text { Gibberella fujikuroi) }\end{array}$ & $1(1.4 \%)$ & yes & $30 \%$ & Vegetable fields & Palestine & [26] \\
\hline
\end{tabular}

* In the studies mentioned above, a quick dip or touch on fungal conidia sporulating on insects were used for pathogenicity confirmation.

\subsection{Presence and/or Production of Insecticidal Metabolite beauvericin in Fusarium spp.}

Beauvericin is a cyclic hexadepsipeptide belonging to the enniatin antibiotic family [28]. It is one of the active constituents of the entomopathogenic fungi Beauveria bassiana (Balsamo) Vuillemin (Hypocreales: Cordycipitaceae), and exhibits insecticidal, antimicrobial and anti-tumor activities. It was first isolated in 1969 from B. bassiana and Isaria fumosorosea Wize (Paecilomyces fumosoroseus (Wize) Brown \& Smith) [29]. Later, it was also reported in other members of entomopathogenic fungal family Cordycipitaceae, such as Isaria tenuipes Peck and Cordyceps cicadae (Miq.) [30].

Gupta et al. reported the first isolation of beauvericin from Fusarium spp. [31], and later, a few studies such as Logrieco et al. [32] and, Stępień and Waśkiewicz [33] studied the production of beauvericin by Fusarium species. Moreover, some reports also reviewed the presence of beauvericin within Fusarium spp. [30,34]. The occurrence of beauvericin in Fusarium spp. and the members of Cordycipitaceae was so frequent that beauvericin was suggested as a chemotaxonomic marker for these fungi $[30,34]$. Due to the importance of beauvericin as an insecticidal metabolite, we also reviewed studies, which reported its isolation and/or the presence in the genome of Fusarium spp. At least 25 different Fusarium spp. produced beauvericin (Table 3).

Enniatins (ENNs) are also among the toxins belonging to the enniatin antibiotic family. They are produced by various Fusarium spp. and are reviewed by Jastoi [34]. The most prevalent ENNs analogs are ENN A, A1, B, and B1 [35]. Like beauvericin, these toxins also exhibit insect-pathogenicity. Numerous studies in the past have reported their entomopathogenicity [36-38]. Although it has been reported that fungi such as F. avenaceum and Fusarium tricinctum (Corda) Sacc. do not produce beauvericin, however, they produce significant amount of ENNs [39-41]. 
Table 2. On-field natural insect mycoses by Fusarium spp. and the pathogenicity confirmation of the obtained isolates.

\begin{tabular}{|c|c|c|c|c|c|c|c|c|}
\hline Fusarium Species & Insect-Host & $\begin{array}{c}\text { Number of Fungal } \\
\text { Isolates and/or } \\
\text { Occurrence } \\
\text { Frequencies } \\
\end{array}$ & $\begin{array}{l}\text { Koch's Postulate } \\
\text { Confirmed (A) }\end{array}$ & $\begin{array}{l}\text { Quantity of Fungal } \\
\text { Concentration } \\
\text { Used in A }\end{array}$ & $\begin{array}{l}\text { Percentage Mortality } \\
\text { during A }\end{array}$ & Plantation & Country & Reference \\
\hline F. acuminatum & $\begin{array}{c}\text { Cephus cinctus Norton } \\
\text { (Hymenoptera: Cephidae) }\end{array}$ & $8(3.7 \%)$ & Yes, with one isolate & $\begin{array}{l}1.5 \times 10^{4}-1.5 \times 10^{8} \\
\text { conidia } / \mathrm{mL}\end{array}$ & $\begin{array}{l}\sim 60 \% \text { at } 1.5 \times 10^{8} \\
\quad \text { conidia } / \mathrm{mL}\end{array}$ & Wheat & USA & [42] \\
\hline F. avenaceum & C. cinctus & $27(12.4 \%)$ & Yes, with one isolate & $\begin{array}{l}1.5 \times 10^{4}-1.5 \times 10^{8} \\
\text { conidia } / \mathrm{mL}\end{array}$ & $\begin{array}{l}\sim 90 \% \text { at } 1.5 \times 10^{8} \\
\quad \text { conidia } / \mathrm{mL}\end{array}$ & Wheat & USA & [42] \\
\hline F. culmorum & C. cinctus & $126(58.1 \%)$ & Yes, with one isolate & $\begin{array}{c}1.5 \times 10^{4}-1.5 \times 10^{8} \\
\text { conidia } / \mathrm{mL}\end{array}$ & $\begin{array}{l}\sim 80 \% \text { at } 1.5 \times 10^{8} \\
\quad \text { conidia } / \mathrm{mL}\end{array}$ & Wheat & USA & [42] \\
\hline F. equiseti & C. cinctus & $31(14.3 \%)$ & Yes, with one isolate & $\begin{array}{l}1.5 \times 10^{4}-1.5 \times 10^{8} \\
\text { conidia } / \mathrm{mL}\end{array}$ & $\begin{array}{l}\sim 80 \% \text { at } 1.5 \times 10^{8} \\
\quad \text { conidia } / \mathrm{mL}\end{array}$ & Wheat & USA & [42] \\
\hline F. merismoides & P. quercivorus & $5(17.86 \%)$ & yes & $\mathrm{n} / \mathrm{a}$ & $7.17 \%$ & Oak logs & Japan & [43] \\
\hline \multirow{4}{*}{ F. oxysporum } & $\begin{array}{l}\text { Brahmina coriacea Hope } \\
\text { (Coleoptera: Scarabaeidae) }\end{array}$ & $262(18.66 \%)$ & yes & $\mathrm{n} / \mathrm{a}$ & $49.63 \%$ & Potato & India & [44] \\
\hline & $\begin{array}{l}\text { Platypus quercivorus Murayama } \\
\text { (Coleoptera: Platypodidae) }\end{array}$ & $4(14.28 \%)$ & yes & $\mathrm{n} / \mathrm{a}$ & $53.93 \%$ & Oak logs & Japan & [43] \\
\hline & $\begin{array}{l}\text { Insects from the orders Homoptera, } \\
\text { Coleoptera and Lepidoptera. }\end{array}$ & $246(70.29 \%)$ & Yes, using one isolate & $10^{8}$ conidia $/ \mathrm{mL}$ & $97.5 \%$ & $\begin{array}{l}\text { Chilli, Palo de rosa } \\
\text { plant and Maize }\end{array}$ & Mexico & [45] \\
\hline & $\begin{array}{c}\text { Planococcus ficus (Signoret) } \\
\text { (Hemiptera: Pseudococcidae) }\end{array}$ & $1(4.55 \%)$ & Yes & $10^{8}$ conidia $/ \mathrm{mL}$ & $50 \%$ & Vines & Portugal & [46] \\
\hline F. proliferatum & $\begin{array}{l}\text { Dryocosmus kuriphilus Yasumatsu } \\
\text { (Hymenoptera: Cynipidae) }\end{array}$ & $2(3.55 \%)$ & yes & $2 \times 10^{6}$ conidia $/ \mathrm{mL}$ & $33 \%$ and $99 \%$ & Chestnut & Italy & [47] \\
\hline F. pseudograminearum & C. cinctus & $25(11.5 \%)$ & Yes, with one isolate & $\begin{array}{c}1.5 \times 10^{4}-1.5 \times 10^{8} \\
\quad \text { conidia } / \mathrm{mL}\end{array}$ & $\begin{array}{l}>95 \% \text { at } 1.5 \times 10^{8} \\
\quad \text { conidia } / \mathrm{mL}\end{array}$ & Wheat & USA & [42] \\
\hline \multirow{4}{*}{ F. solani } & B. coriacea & $120(8.6 \%)$ & yes & $\mathrm{n} / \mathrm{a}$ & $42.59 \%$ & Potato & India & [44] \\
\hline & P. quercivorus & $1(3.5 \%)$ & yes & $\mathrm{n} / \mathrm{a}$ & $47.33 \%$ & Oak logs & Japan & [43] \\
\hline & $\begin{array}{l}\text { Tetanops myopaeformis Röder } \\
\text { (Diptera: Ulidiidae) }\end{array}$ & $44 \%$ & yes & $>10^{6}$ conidia $/ \mathrm{mL}$ & $\begin{array}{l}\text { Considered pathogenic } \\
\text { only after Koch's } \\
\text { postulate verification }\end{array}$ & $\begin{array}{l}\text { Wheat during } \\
\text { collection and } \\
\text { Sugarbeet in the } \\
\text { previous year }\end{array}$ & USA & [48] \\
\hline & $\begin{array}{c}\text { Planococcus ficus (Signoret) } \\
\text { (Hemiptera: Pseudococcidae) }\end{array}$ & $2(9.10 \%)$ & Yes & $10^{8}$ conidia $/ \mathrm{mL}$ & $45 \%$ & Vines & Portugal & [46] \\
\hline
\end{tabular}


Table 2. Cont

\begin{tabular}{|c|c|c|c|c|c|c|c|c|}
\hline Fusarium Species & Insect-Host & $\begin{array}{l}\text { Number of Fungal } \\
\text { Isolates and/or } \\
\text { Occurrence } \\
\text { Frequencies }\end{array}$ & $\begin{array}{l}\text { Koch's Postulate } \\
\text { Confirmed (A) }\end{array}$ & $\begin{array}{l}\text { Quantity of Fungal } \\
\text { Concentration } \\
\text { Used in A }\end{array}$ & $\begin{array}{l}\text { Percentage Mortality } \\
\text { during A }\end{array}$ & Plantation & Country & Reference \\
\hline \multirow{4}{*}{$\begin{array}{l}\text { F. verticillioides } \\
\text { (=F. moniliforme } \\
\text { or F. fujikuroi; } \\
\text { teleomorph: } \\
\text { Gibberella fujikuroi) }\end{array}$} & $\begin{array}{l}\text { Insects from the orders Homoptera, } \\
\text { Coleoptera and Lepidoptera. }\end{array}$ & $100(28.57 \%)$ & Yes, using one isolate & $10^{8}$ conidia $/ \mathrm{mL}$ & $96.6 \%$ & Papaya and Maize & Mexico & [45] \\
\hline & $\begin{array}{l}\text { Ceratovacuna lanigera Zehntner } \\
\text { (Homoptera: Aphididae) }\end{array}$ & $\begin{array}{l}\text { Total four strains } \\
\text { isolated }\end{array}$ & $\begin{array}{l}\text { Yes; one isolate was } \\
\text { re-tested in field }\end{array}$ & $\begin{array}{l}10^{7} \mathrm{CFU} / \mathrm{mL} \text { for Koch's } \\
\text { postulate; } 10^{8} \mathrm{CFU} / \mathrm{gm} \\
\text { powder for the field }\end{array}$ & $\begin{array}{l}60 \% \text { effective mortality } \\
\text { in field }\end{array}$ & Sugarcane & India & [49] \\
\hline & $\begin{array}{l}\text { Tropidacris collaris Stoll } \\
\text { (Orthoptera: Acridoidea) }\end{array}$ & $\begin{array}{l}\text { One strain isolated } \\
\text { for further testing }\end{array}$ & $\begin{array}{l}\text { Tested on another } \\
\text { insect }\end{array}$ & $2.8 \times 10^{6}$ conidia $/ \mathrm{mL}$ & $\begin{array}{l}58 \% \text { against Ronderosia } \\
\text { bergi Stål } \\
\text { (Orthoptera: Acrididae) }\end{array}$ & Dense woodland & Argentina & [50] \\
\hline & $\begin{array}{l}\text { Planococcus ficus (Signoret) } \\
\text { (Hemiptera: Pseudococcidae) }\end{array}$ & $1(4.55 \%)$ & Yes & $10^{8}$ conidia $/ \mathrm{mL}$ & $40 \%$ & Vines & Portugal & [46] \\
\hline
\end{tabular}

Table 3. Studies reporting the production and/or presence of genetic loci in Fusarium spp. encoding for the insecticidal metabolite beauvericin

\begin{tabular}{|c|c|c|c|}
\hline Fusarium Species & Report of Genes, or Presence in Genome & In-Vitro or In-Vivo Production & References \\
\hline F. acuminatum & Y & Y & {$[32,33,51]$} \\
\hline F. ananatum & Y & Y & {$[33,52]$} \\
\hline F. anthophilum & $\mathrm{Y}$ & $\mathrm{Y}$ & {$[32,33]$} \\
\hline F. beomiforme & - & $\mathrm{Y}$ & {$[32,52]$} \\
\hline F. circinatum & $\mathrm{Y}$ & $\mathrm{Y}$ & {$[52,53]$} \\
\hline F. concentricum & Y & $\mathrm{Y}$ & [33] \\
\hline F. dlamini & - & Y & {$[32]$} \\
\hline F. equiseti & - & Y & {$[32]$} \\
\hline F. longipes & - & Y & {$[32]$} \\
\hline F. mangiferae & $\mathrm{Y}$ & $\mathrm{Y}$ & [53] \\
\hline F. nygamai & Y & $\mathrm{Y}$ & {$[32,33]$} \\
\hline F. oxysporum & $\mathrm{Y}$ & $\mathrm{Y}$ & {$[32,33]$} \\
\hline F. poae & $\mathrm{Y}$ & $\mathrm{Y}$ & {$[32,33,39,54$} \\
\hline
\end{tabular}


Table 3. Cont.

\begin{tabular}{|c|c|c|c|}
\hline Fusarium Species & Report of Genes, or Presence in Genome & In-Vitro or In-Vivo Production & References \\
\hline F. proliferatum & $\mathrm{Y}$ & $\mathrm{Y}$ & {$[33,55-57]$} \\
\hline F. redolens & - & $\mathrm{Y}$ & [51] \\
\hline F. sambucinum & - & $\mathrm{Y}$ & [32] \\
\hline F. semitectum & - & $\mathrm{Y}$ & [31] \\
\hline F. sporotrichioides & - & $\mathrm{Y}$ & {$[33,39,41]$} \\
\hline F. subglutinans & $\mathrm{Y}$ & $\mathrm{Y}$ & {$[32,33]$} \\
\hline F.temperatum & $\mathrm{Y}$ & $\mathrm{Y}$ & [33] \\
\hline F. glubosum & - & $\mathrm{Y}$ & [56] \\
\hline F. guttiforme & - & $\mathrm{Y}$ & [52] \\
\hline F. konzum & - & $\mathrm{Y}$ & [58] \\
\hline F. pseudoanthophilum & - & $\mathrm{Y}$ & [52] \\
\hline $\begin{array}{c}\text { F. verticillioides } \\
(=\text { F. moniliforme } \\
\text { or F. fujikuroi; teleomorph: Gibberella fujikuroi) }\end{array}$ & Y & Y & {$[33,48,57]$} \\
\hline
\end{tabular}

Note: $Y$ signifies yes and the minus (-) sign signifies 'no report yet'. 


\subsection{Proof-Of-Concept Studies on Fusarium (oxysporum) Entomopathogenicity}

Although the occurrence of insecticolous fusaria is very common, there was not enough evidence to propose that Fusarium spp. were "real" entomopathogens, alike Beauveria or Metarhizium. In this direction, Navarro-Velasco et al. presented a detailed study based on histological evidence and dose-response curves highlighting the infectivity of F. oxysporum in G. mellonella larvae [7]. The study demonstrated: (a) The hyphal proliferation within the host hemocoel; (b) fungal interactions with host hemocytes; (c) progressive melanization; and (d) host colonization of the fungus. It was demonstrated that larval mortalities by F. oxysporum occurred through an active infection mechanism instead of a merely physical effect caused by the fungal conidia [7]. A similar study was conducted by Coleman et al. suggesting that the entomopathogenicity of fusaria fluctuated with varying temperatures and fungal conidial morphology [8]. Muñoz-Gómez et al. undertook a quantitative proteomics approach to identify the proteins and peptides involved in an elicited immune response in the hemolymph of G. mellonella larva infected with F. oxysporum microconidia [59]. Moreover, the importance of mitogen-activated protein kinases (MAPKs) of Fusarium has been demonstrated in its pathogenicity against insect larva [60]. In addition, a few studies have reported the presence of antifungal peptides after larval immunization by fusaria [61,62]. These studies are the proof-of-concept investigations, which demonstrate the entomopathogenicity of Fusarium spp. like F. oxysporum.

\subsubsection{Effect of Fungal Morphology and Ambient Temperature on Insect Mortality}

Coleman et al. reported that both clinical and environmental fusaria are able to cause mortality among G. mellonella larvae. Larval moralities were noticed at $30^{\circ} \mathrm{C}$ as well as $37^{\circ} \mathrm{C}$, however, larval killings were more rapid at $30^{\circ} \mathrm{C}$ [8]. Conidial morphology is also vital and it was found that the fungal macroconidia were more virulent than the microconidia.

3.3.2. Mitogen-Activated Protein Kinase (MAPK) Cascades: A Case of Key Fungal Pathways Responsible in Recognizing Cues during Insect Pathogenesis by Fusarium (oxysporum)

A fungal response to environmental and host cues is regulated by many functional biochemical pathways. Mitogen-activated protein kinase (MAPK) cascades are one of such pathways responsible in perceiving these molecular cues. The majority of the ascomycetous fungi, except Saccharomyces cerevisiae Meyen ex Hansen, possess only three MAPKs. These MAPKs are orthologous to Fusarium MAPK ((Fmk1) (or S. cerevisiae Fus3/Kss1)), yeast MAPK (Mpk1) and high-osmolarity glycerol MAPK (Hog1) [63]. The Fusarium MAPK, Fmk1, regulates infection-related morphogenesis and invasive growth, and Mpk1 is necessary for fungal cell wall remodeling and integrity. Another MAPK, Hog1, is crucial for adaptive response during hyperosmotic stress, besides mediating sensitivities to certain fungicides [60].

Segorbe et al. studied the contribution of these three MAPKs within F. oxysporum, with respect to the development, virulence and stress response in the insect-host G. mellonella [60]. It was found that strains with Mpk1 or Hog1 deletions showed a significant decrease in virulence in comparison with the wild type strain. In addition, virulence was further decreased significantly in the double mutant strains with Mpk1 and Hog1 deletions, when compared to single deletion mutants of these MAPKs. This suggests that Hog1 and Mpk1 have distinct and additive virulence functions in F. oxysporum pathogenesis in G. mellonella [60].

\subsubsection{Production of Antimicrobial Peptides in Insect Larva Post Fusarium Immunization}

A few studies have investigated the presence of antifungal peptides in the hemolymph of immune stimulated G. mellonella larva. Brown et al. reported moricin-like peptides in the hemolymph of immune stimulated G. mellonella larva [61]. These peptides exhibited in vitro inhibition of F. oxysporum and F. graminearum. In another study, an increase of Galleria defensin, lysozyme, and proline-rich peptide 2 was observed in G. mellonella hemolymph after immunization by F. oxysporum [62]. The maximum concentrations of these peptides were noticed $72 \mathrm{~h}$ post-immunization. 


\subsubsection{Induced Protein Expression in Insect Larva during Fusarium (oxysporum) Infection}

Muñoz-Gómez et al. studied the proteins which were expressed differentially within the hemolymph of G. mellonella, in the control and immunized larval sets, when two different concentrations of $F$. oxysporum, i.e., $10^{4}$ or $10^{6}$ microconidia/mL were injected. The study also investigated the changes in immune response when the temperature was raised from $25^{\circ} \mathrm{C}$ to $37^{\circ} \mathrm{C}$. They observed an expression change of over 50 proteins, and 17 of them were supposed to be involved in the insect's immune response [59]. Here we reviewed some of those immune response related proteins which got differentially regulated at $25{ }^{\circ} \mathrm{C}$. We also briefly discuss the general role of those proteins in insects.

\section{Crucial Down-Regulated Proteins}

Arylphorin and Apolipophorin, which were supposed to be quite abundant in the hemolymph, were down-regulated after F. oxysporum invasion [59]. Ayrlphorins is a class of $\sim 500 \mathrm{kDa}$ glycoproteins which are produced by the insect larva as reserves during the metamorphosis and egg development stages [64]. Apolipophorins help in lipid transport and are thought to be associated with antimicrobial activities, as lipids are secreted to prevent a microbial invasion. In particular, Apolipophorin III was found to be the most down-regulated protein in the study by Muñoz-Gómez et al. (2014) [59]. This protein increases the antibacterial activity within the hemolymph, and the production of superoxide by the hemocytes [65]. Muñoz-Gómez et al. hypothesized that it may stimulate antimycotic activities within the hemolymph. Another glycoprotein, i.e., larval hemolymph protein was also found to be down-regulated [59].

Hexamerins were also found to be down-regulated. They are regularly secreted by the larval fat body and stored within the hemolymph, and during metamorphosis they return to the larval fat body to be processed [66]. Transferrin removes the essential iron ions during pathogen invasion and makes the insect hemocoel unsuitable for microbial colonization [67]. These proteins undertake antibacterial iron-withholding strategies within the insects [68]. Muñoz-Gómez et al. found that the protein Transferrin was also down-regulated which, according to them, act as an antimycotic mediator enhancing insect survival by preventing oxidative stress [59].

\section{Crucial Up-Regulated Proteins}

Cationic protein 8 precursor was also found to be an abundant protein which was upregulated extraordinarily [32]. Kim et al. reported that it functions as an opsonin, which promotes the uptake of invading microbes into hemocytes, and therefore, contributing in phagocytosis by hemocytes [69]. Another up-regulated protein, i.e., Hemolin, is a member of the immunoglobulin protein superfamily, which interacts in lepidopteran insects as an opsonin. Hemolin is associated with hemocytes, and as an opsonin, it facilitates recognition of pathogens and mediates hemocytic immune response [70-72]. Increased Hemolin can be seen as an insect response towards mycotic infection as its expression was always up-regulated when microconidia concentration was increased [59].

Lysozyme was also up-regulated, which is a well-known anti-bacterial enzyme, and is cold-adapted to work in insects dwelling at lower temperatures [73]. Melanization is an important physiological change occurring inside hemocoel when an insect is invaded by a pathogen, for example, Beauveria. Interestingly, Lysozymes have also been reported for its anti-melanization activity inside mosquitoes [74].

During an infection process, the immune cells migrate, adhere and phagocytose invading pathogens, and contribute to wound repair. Hence, cell adhesion and phagocytosis are quite critical in eliminating infection-causing microbes. These two processes depend on the dynamics of the Actin network, i.e., Actin filaments polymerization and depolymerization [75]. Up-regulation of Actin during F. oxysporum invasion of G. mellonella larva further highlights the entomopathogenicity of the fungus [59]. 


\section{Safety and Side Effect of Using Entomopathogenic Fusaria on Plants, and Possible Genetic Attunements Facilitating Use as a Biopesticide}

Studies focusing on the safety of using insect-pathogenic fusaria on plants showed mixed results. Some previous investigations have documented their safety in terms of fungal application on plants. An investigation was conducted to test the infectivity of F. oxysporum isolated from the brown planthopper, Nilaparvata lugens Stål (Hemiptera: Delphacidae) on the rice, cotton and tomato plants. Four different fungal treatments, i.e., soil, root, seed and leaf, were used to test the possibility of an infection. However, the results were negative in all of the cases and the entomopathogenic strain was found safe for the plants [76]. In another study, conidial sprays of Fusarium on grape phylloxera Daktulosphaira vitifoliae Fitch (Hemiptera: Phylloxeridae) reduced insect populations encompassing different life stages ranging from eggs, larva and adults [77]. Sprayed Fusarium was found to be a saprophyte associated with grape leaves and caused no infections in the plant [77].

On the contrary, a few studies reported the infectivity of entomopathogenic fusaria on plants. Strains of F. oxysporum, F. solani and F. roseum from Sitona hispidula Fabricius and Sitona flavescens Marsh (Coleoptera: Curculionidae) were also found pathogenic to these larvae. However, isolated F. oxysporum exhibited pathogenicity to clover Trifolium pretense L. [78].

To access the infectivity of entomopathogenic F. oxysporum on tomato plants, Navarro-Velasco et al. studied the effects of different fungal mutant strains on the plant [7]. Deletion of different loci led to distinct results in terms of their pathogenicity towards the tomato plant and G. mellonella larval killings. Mutants without the locus fmk1 [79], the heterotrimeric $G$ protein $\beta$-subunit (fgb1) [80], or $\beta$-1,3-glucanosyltransferase (gas1) [81] exhibited marginal or no infectivity to the tomato plant, however, all these strains exhibited considerable entomopathogenicity. Hence, Navarro-Velasco et al. demonstrated that through specific mutations, phytopathogenicity of Fusarium strains can be checked and they can be attuned for biological control of insects [7].

\section{Conclusions}

Fusarium spp. has long been thought of as an opportunistic insect pathogenic fungi, or saprophytes, which colonizes decaying bodies of insects. Furthermore, as fusaria are well-known plant pathogens, such generalizations only grow stronger. With increasing evidence of in-field insect mycoses by fusaria, it's time to reconsider its biological function besides being phytopathogens and saprophytes. Studies summarized within this review range from ecological to experimental and immunological, and will help researchers to gain insights into the role of fusaria as entomopathogens. It was noted that fusaria could exhibit mutualism with insects, however, this property was generally restricted to strains belonging to the $F$. solani species complex. More proof-of-concept studies on insects from different orders will further strengthen the claims of the entomopathogenicity of different Fusarium species. It has been observed that entomopathogenic fusaria can be safe for plants. Furthermore, phytopathogenicity of entomopathogenic fusaria can be attenuated through deletions of a few loci. We urge for the development of robust markers which could distinguish fusaria that solely exhibit entomopathogenicity. Additionally, we stress on the need for molecular studies differentiating between the fungal genetic loci solely used in entomopathogenicity, from those imparting phytopathogenicity in fusaria. Such studies would facilitate the development of a few Fusarium strains as biological control agents of some insect-pests of interest.

Author Contributions: Conceptualization, L.S., G.M.; methodology, L.S.; investigation, L.S.; resources, G.M.; data curation, L.S; writing - original draft preparation, L.S.; writing-review and editing, G.M.; supervision, G.M.; project administration, G.M.; funding acquisition, G.M.

Funding: Research was funded by the National Funds by FCT-Portuguese Foundation for Science and Technology, the project EcoVitis-Maximizing ecosystem services in “Douro Demarcated Region" vineyards, funded by FEADER and by National Funds under the Rural Development Programme (PRODER)—PA 24043, 2011-2014, under the fellowship BI/PRODER/Projeto24043/UTAD/2012; under the project UID/AGR/04033/2013; and from European Investment Funds by FEDER/COMPETE/POCI-Operational Competitiveness and Internationalization Programme, under Project POCI-01-0145-FEDER-006958. 
Acknowledgments: We would like to acknowledge the meaningful comments provided by the academic editor and the two reviewers on this manuscript. The work is a part of L. Sharma's dissertation at the University of Trás-os-Montes and Alto Douro, UTAD, Vila Real, Portugal. We would like to thank the technicians of the Sogevinus Finewines SA and Real Companhia Velha for their constant co-operation during the investigation. English editing by Kush Sharma, University of Manchester, England, U.K., is also appreciated.

Conflicts of Interest: The authors declare no conflicts of interest.

\section{References}

1. Al-Hatmi, A.M.S.; Meis, J.F.; de Hoog, G.S. Fusarium: Molecular diversity and intrinsic drug resistance. PLoS Pathog. 2016, 12, e1005464. [CrossRef] [PubMed]

2. O'Donnell, K.; Rooney, A.P.; Proctor, R.H.; Brown, D.W.; McCormick, S.P.; Ward, T.J.; Frandsen, R.J.N.; Lysøe, E.; Rehner, S.A.; Aoki, T.; et al. Phylogenetic analyses of rpb1 and rpb2 support a middle cretaceous origin for a clade comprising all agriculturally and medically important fusaria. Fungal Genet. Biol. 2013, 52, 20-31. [CrossRef] [PubMed]

3. Dean, R.; Van Kan, J.A.L.; Pretorius, Z.A.; Hammond-Kosack, K.E.; Di Pietro, A.; Spanu, P.D.; Rudd, J.J.; Dickman, M.; Kahmann, R.; Ellis, J.; et al. The top 10 fungal pathogens in molecular plant pathology. Mol. Plant Pathol. 2012, 13, 414-430. [CrossRef] [PubMed]

4. Ortoneda, M.; Guarro, J.; Madrid, M.P.; Caracuel, Z.; Roncero, M.I.G.; Mayayo, E.; Di Pietro, A. Fusarium oxysporum as a multihost model for the genetic dissection of fungal virulence in plants and mammals. Infect. Immun. 2004, 72, 1760-1766. [CrossRef] [PubMed]

5. Nelson, P.E.; Dignani, M.C.; Anaissie, E.J. Taxonomy, biology, and clinical aspects of Fusarium species. Clin. Microbiol. Rev. 1994, 7, 479-504. [CrossRef] [PubMed]

6. Nucci, M.; Anaissie, E. Fusarium infections in immunocompromised patients. Clin. Microbiol. Rev. 2007, 20, 695-704. [CrossRef] [PubMed]

7. Navarro-Velasco, G.Y.; Prados-Rosales, R.C.; Ortíz-Urquiza, A.; Quesada-Moraga, E.; Di Pietro, A. Galleria mellonella as model host for the trans-kingdom pathogen Fusarium oxysporum. Fungal Genet. Biol. 2011, 48, 1124-1129. [CrossRef] [PubMed]

8. Coleman, J.J.; Wasmann, C.C.; Usami, T.; White, G.J.; Temporini, E.D.; McCluskey, K.; VanEtten, H.D. Characterization of the gene encoding pisatin demethylase (fopda1) in Fusarium oxysporum. Mol. Plant Microbe Interact. 2011, 24, 1482-1491. [CrossRef] [PubMed]

9. Wollenweber, H.W.; Reinking, O.A. Die Fusarien, Ihre Beschreibung, Schadwirkung und Bekämpfung; Verlag Paul Parey: Berlin, Germany, 1935; p. 355. Available online: https:/ / catalog.hathitrust.org/Record/001998002 (accessed on 24 November 2018).

10. Gordon, W.L. The occurrence of fusarium species in canada: Vi. Taxonomy and geographic distribution of Fusarium species on plants, insects, and fungi. Can. J. Bot. 1959, 37, 257-290. [CrossRef]

11. Li, H.K. Observation on the pathogenic microorganism of main rice insect pests. Microbiology 1984, 11, 3-6.

12. Feng-Yan, B.; Quing-Tao, C. Fusarium species on some insects from china. Acta Mycol. Sin. 1991, 10, $120-128$.

13. Teetor-Barsch, G.H.; Roberts, D.W. Entomogenous Fusarium species. Mycopathologia 1983, 84, 3-16. [CrossRef] [PubMed]

14. Claydon, N.; Grove, J.F. Fusarium as an insect pathogen. In The applied mycology of Fusarium; Moss, M.O., Smith, J.E., Eds.; Cambridge University Press: Cambridge, UK, 1984; pp. 117-128. Available online: https:/ / www.nhbs.com/the-applied-mycology-of-fusarium-book (accessed on 24 November 2018).

15. O’Donnell, K.; Humber, R.A.; Geiser, D.M.; Kang, S.; Park, B.; Robert, V.A.; Crous, P.W.; Johnston, P.R.; Aoki, T.; Rooney, A.P.; et al. Phylogenetic diversity of insecticolous fusaria inferred from multilocus DNA sequence data and their molecular identification via Fusarium-ID and Fusarium MLST. Mycologia 2012, 104, 427-445. [CrossRef] [PubMed]

16. O’Donnell, K.; Sink, S.; Libeskind-Hadas, R.; Hulcr, J.; Kasson, M.T.; Ploetz, R.C.; Konkol, J.L.; Ploetz, J.N.; Carrillo, D.; Campbell, A.; et al. Discordant phylogenies suggest repeated host shifts in the Fusarium-Euwallacea ambrosia beetle mutualism. Fungal Genet. Biol. 2015, 82, 277-290. [CrossRef] [PubMed] 
17. Kasson, M.T.; O’Donnell, K.; Rooney, A.P.; Sink, S.; Ploetz, R.C.; Ploetz, J.N.; Konkol, J.L.; Carrillo, D.; Freeman, S.; Mendel, Z.; et al. An inordinate fondness for Fusarium: Phylogenetic diversity of fusaria cultivated by ambrosia beetles in the genus Euwallacea on avocado and other plant hosts. Fungal Genet. Biol. 2013, 56, 147-157. [CrossRef] [PubMed]

18. Short, D.P.G.; O’Donnell, K.; Stajich, J.E.; Hulcr, J.; Kijimoto, T.; Berger, M.C.; Macias, A.M.; Spahr, E.J.; Bateman, C.C.; Eskalen, A.; et al. PCR multiplexes discriminate Fusarium symbionts of invasive Euwallacea ambrosia beetles that inflict damage on numerous tree species throughout the United States. Plant Dis. 2016, 101, 233-240. [CrossRef]

19. Scully, E.D.; Hoover, K.; Carlson, J.; Tien, M.; Geib, S.M. Proteomic analysis of Fusarium solani isolated from the asian longhorned beetle, Anoplophora glabripennis. PLoS ONE 2012, 7, e32990. [CrossRef] [PubMed]

20. Hajek, A.; Goettel, M. Guidelines for evaluating effects of entomopathogens on non-target organisms. In Field Manual of Techniques in Invertebrate Pathology: Application and Evaluation of Pathogens for Control of Insects and Other Invertebrate Pests, 2nd ed.; Lacey, L.A., Kaya, H.K., Eds.; Springer: Dordrecht, The Netherlands, 2007; pp. 815-833.

21. Panyasiri, C.; Attathom, T.; Poehling, H.-M. Pathogenicity of entomopathogenic fungi-potential candidates to control insect pests on tomato under protected cultivation in Thailand. J. Plant Dis. Prot. 2007, 114, 278-287. [CrossRef]

22. Da Silva Santos, A.C.; Oliveira, R.L.S.; da Costa, A.F.; Tiago, P.V.; de Oliveira, N.T. Controlling dactylopius opuntiae with Fusarium incarnatum-equiseti species complex and extracts of Ricinus communis and Poincianella pyramidalis. J. Pest Sci. 2016, 89, 539-547. [CrossRef]

23. Zimmermann, G. The 'Galleria bait method' for detection of entomopathogenic fungi in soil. J. Appl. Entomol. 1986, 102, 213-215. [CrossRef]

24. Sharma, L.; Oliveira, I.; Torres, L.; Marques, G. Entomopathogenic fungi in Portuguese vineyards soils: Suggesting a 'Galleria-Tenebrio-bait method' as bait-insects Galleria and Tenebrio significantly underestimate the respective recoveries of Metarhizium (robertsii) and Beauveria (bassiana). MycoKeys 2018, 38, 1-23. [CrossRef]

25. Sharma, L.; Oliveira, I.; Raimundo, F.; Torres, L.; Marques, G. Soil chemical properties barely perturb the abundance of entomopathogenic Fusarium oxysporum: A case study using a generalized linear mixed model for microbial pathogen occurrence count data. Pathogens 2018, 7, 89. [CrossRef] [PubMed]

26. Ali-Shtayeh, M.S.; Mara'i, A.-B.B.M.; Jamous, R.M. Distribution, occurrence and characterization of entomopathogenic fungi in agricultural soil in the Palestinian area. Mycopathologia 2003, 156, 235-244. [CrossRef]

27. Sun, B.-D.; Liu, X.-Z. Occurrence and diversity of insect-associated fungi in natural soils in China. Appl. Soil Ecol. 2008, 39, 100-108. [CrossRef]

28. Wang, Q.; Xu, L. Beauvericin, a bioactive compound produced by fungi: A short review. Molecules 2012, 17, 2367-2377. [CrossRef] [PubMed]

29. Hamill, R.L.; Higgens, C.E.; Boaz, H.E.; Gorman, M. The structure of Beauvericin, a new depsipeptide antibiotic toxic to Artemia salina. Tetrahedron Lett. 1969, 10, 4255-4258. [CrossRef]

30. Wang, X.; Gong, X.; Li, P.; Lai, D.; Zhou, L. Structural diversity and biological activities of cyclic depsipeptides from fungi. Molecules 2018, 23, 169. [CrossRef] [PubMed]

31. Gupta, S.; Krasnoff, S.B.; Underwood, N.L.; Renwick, J.A.; Roberts, D.W. Isolation of beauvericin as an insect toxin from Fusarium semitectum and Fusarium moniliforme var. subglutinans. Mycopathologia 1991, 115, 185-189. [CrossRef] [PubMed]

32. Logrieco, A.; Moretti, A.; Castella, G.; Kostecki, M.; Golinski, P.; Ritieni, A.; Chelkowski, J. Beauvericin production by Fusarium species. Appl. Environ. Microbiol. 1998, 64, 3084-3088. [PubMed]

33. Stepien, L.; Waskiewicz, A. Sequence divergence of the enniatin synthase gene in relation to production of beauvericin and enniatins in Fusarium species. Toxins 2013, 5, 537-555. [CrossRef] [PubMed]

34. Jestoi, M. Emerging Fusarium-mycotoxins fusaproliferin, beauvericin, enniatins, and moniliformin: A review. CRC Crit. Rev. Food Sci. Nutr. 2008, 48, 21-49. [CrossRef] [PubMed]

35. Prosperini, A.; Berrada, H.; Ruiz, M.J.; Caloni, F.; Coccini, T.; Spicer, L.J.; Perego, M.C.; Lafranconi, A. A review of the mycotoxin Enniatin B. Front. Public Health 2017, 5, 304. [CrossRef] [PubMed]

36. Grove, J.F.; Pople, M. The insecticidal activity of Beauvericin and the Enniatin complex. Mycopathologia 1980, 70, 103-105. [CrossRef] 
37. Strongman, D.B.; Strunz, G.M.; Giguère, P.; Yu, C.-M.; Calhoun, L. Enniatins from Fusarium avenaceum isolated from balsam fir foliage and their toxicity to spruce budworm larvae, Choristoneura fumiferana (Clem.) (Lepidoptera: Tortricidae). J. Chem. Ecol. 1988, 14, 753-764. [CrossRef] [PubMed]

38. Mulè, G.; D'Ambrosio, A.; Logrieco, A.; Bottalico, A. Toxicity of mycotoxins of Fusarium sambucinum for feeding in Galleria mellonella. Entomol. Exp. Appl. 1992, 62, 17-22. [CrossRef]

39. Kokkonen, M.; Ojala, L.; Parikka, P.; Jestoi, M. Mycotoxin production of selected Fusarium species at different culture conditions. Int. J. Food Microbiol. 2010, 143, 17-25. [CrossRef] [PubMed]

40. Jestoi, M.; Rokka, M.; Yli-Mattila, T.; Parikka, P.; Rizzo, A.; Peltonen, K. Presence and concentrations of the Fusarium-related mycotoxins beauvericin, enniatins and moniliformin in Finnish grain samples. Food Addit. Contam. 2004, 21, 794-802. [CrossRef] [PubMed]

41. Jestoi, M.N.; Paavanen-Huhtala, S.; Parikka, P.; Yli-Mattila, T. In vitro and in vivo mycotoxin production of Fusarium species isolated from Finnish grains. Arch. Phytopathol. Plant Prot. 2008, 41, 545-558. [CrossRef]

42. Wenda-Piesik, A.; Sun, Z.; Grey, W.E.; Weaver, D.K.; Morrill, W.L. Mycoses of wheat stem sawfly (Hymenoptera: Cephidae) larvae by Fusarium spp. isolates. Environ. Entomol. 2009, 38, 387-394. [CrossRef] [PubMed]

43. Qi, H.-Y.; Wang, J.-G.; Endoh, R.; Takeuchi, Y.; Tarno, H.; Futai, K. Pathogenicity of microorganisms isolated from the oak platypodid, Platypus quercivorus (Murayama) (Coleoptera: Platypodidae). Appl. Entomol. Zool. 2011, 46, 201-210. [CrossRef]

44. Sharma, A.; Chandla, V.K.; Thakur, D.R. Biodiversity and pathogenicity potential of mycoflora associated with Brahmina coriacea in potato fields of north-western Indian hills. J. Entomol. 2012, 9, 319-331. [CrossRef]

45. Torres-Barragán; Anaya, A.L.; Alatorre, R.; Toriello, C. Entomopathogenic fungi from ‘El Eden' Ecological Reserve, Quintana Roo, Mexico. Mycopathologia 2004, 158, 61-71. [CrossRef]

46. Sharma, L.; Gonçalves, F.; Oliveira, I.; Torres, L.; Marques, G. Insect-associated fungi from naturally mycosed vine mealybug Planococcus ficus (Signoret) (Hemiptera: Pseudococcidae). Biocontrol Sci. Technol. 2018, 28, 122-141. [CrossRef]

47. Tosi, L.; Beccari, G.; Rondoni, G.; Covarelli, L.; Ricci, C. Natural occurrence of Fusarium proliferatum on chestnut in Italy and its potential entomopathogenicity against the Asian chestnut gall wasp Dryocosmus kuriphilus. J. Pest Sci. 2015, 88, 369-381. [CrossRef]

48. Majumdar, A.; Boetel, M.A.; Jaronski, S.T. Discovery of Fusarium solani as a naturally occurring pathogen of sugarbeet root maggot (Diptera: Ulidiidae) pupae: Prevalence and baseline susceptibility. J. Invertebr. Pathol. 2008, 97, 1-8. [CrossRef] [PubMed]

49. Mehetre, S.; Mukherjee, P.; Kale, S. Natural occurrence of Gibberella fujikuroi and its potential for control of the woolly aphid Ceratovacuna lanigera (Homoptera: Aphididae) in Indian sugarcane plantations. Biocontrol. Sci. Technol. 2008, 18, 215-220. [CrossRef]

50. Pelizza, S.A.; Stenglein, S.A.; Cabello, M.N.; Dinolfo, M.I.; Lange, C.E. First record of Fusarium verticillioides as an entomopathogenic fungus of grasshoppers. J. Insect Sci. 2011, 11, 70. [CrossRef] [PubMed]

51. Xu, L.-J.; Liu, Y.-S.; Zhou, L.-G.; Wu, J.-Y. Optimization of a liquid medium for beauvericin production in Fusarium redolens dzf2 mycelial culture. Biotechnol. Bioprocess Eng. 2010, 15, 460-466. [CrossRef]

52. Fotso, J.; Leslie, J.F.; Smith, J.S. Production of beauvericin, moniliformin, fusaproliferin, and fumonisins b(1), b(2), and b(3) by fifteen ex-type strains of Fusarium species. Appl. Environ. Microbiol. 2002, 68, 5195-5197. [CrossRef] [PubMed]

53. Wiemann, P.; Sieber, C.M.K.; von Bargen, K.W.; Studt, L.; Niehaus, E.-M.; Espino, J.J.; Huß, K.; Michielse, C.B.; Albermann, S.; Wagner, D.; et al. Deciphering the cryptic genome: Genome-wide analyses of the rice pathogen Fusarium fujikuroi reveal complex regulation of secondary metabolism and novel metabolites. PLoS Pathog. 2013, 9, e1003475. [CrossRef] [PubMed]

54. Thrane, U.; Adler, A.; Clasen, P.E.; Galvano, F.; Langseth, W.; Lew, H.; Logrieco, A.; Nielsen, K.F.; Ritieni, A. Diversity in metabolite production by Fusarium langsethiae, Fusarium poae, and Fusarium sporotrichioides. Int. J. Food Microbiol. 2004, 95, 257-266. [CrossRef] [PubMed]

55. Bottalico, A.; Logrieco, A.; Ritieni, A.; Moretti, A.; Randazzo, G.; Corda, P. Beauvericin and fumonisin b1 in preharvest Fusarium moniliforme maize ear rot in sardinia. Food Addit. Contam. 1995, 12, 599-607. [CrossRef] [PubMed] 
56. Shephard, G.S.; Sewram, V.; Nieuwoudt, T.W.; Marasas, W.F.; Ritieni, A. Production of the mycotoxins fusaproliferin and beauvericin by south african isolates in the Fusarium section liseola. J. Agric. Food Chem. 1999, 47, 5111-5115. [CrossRef] [PubMed]

57. Liuzzi, V.C.; Mirabelli, V.; Cimmarusti, M.T.; Haidukowski, M.; Leslie, J.F.; Logrieco, A.F.; Caliandro, R.; Fanelli, F.; Mulè, G. Enniatin and beauvericin biosynthesis in Fusarium species: Production profiles and structural determinant prediction. Toxins 2017, 9, 45. [CrossRef] [PubMed]

58. Leslie, J.F.; Zeller, K.A.; Logrieco, A.; Mulè, G.; Moretti, A.; Ritieni, A. Species diversity of and toxin production by Gibberella fujikuroi species complex strains isolated from native prairie grasses in Kansas. Appl. Environ. Microbiol. 2004, 70, 2254-2262. [CrossRef] [PubMed]

59. Muñoz-Gómez, A.; Corredor, M.; Benítez-Páez, A.; Peláez, C. Development of quantitative proteomics using itraq based on the immunological response of Galleria mellonella larvae challenged with Fusarium oxysporum microconidia. PLoS ONE 2014, 9, e112179. [CrossRef] [PubMed]

60. Segorbe, D.; Di Pietro, A.; Pérez-Nadales, E.; Turrà, D. Three Fusarium oxysporum mitogen-activated protein kinases (MAPKs) have distinct and complementary roles in stress adaptation and cross-kingdom pathogenicity. Mol. Plant Pathol. 2017, 18, 912-924. [CrossRef] [PubMed]

61. Brown, S.E.; Howard, A.; Kasprzak, A.B.; Gordon, K.H.; East, P.D. The discovery and analysis of a diverged family of novel antifungal moricin-like peptides in the wax moth Galleria mellonella. Insect Biochem. Mol. Biol. 2008, 38, 201-212. [CrossRef] [PubMed]

62. Mak, P.; Zdybicka-Barabas, A.; Cytryńska, M. A different repertoire of Galleria mellonella antimicrobial peptides in larvae challenged with bacteria and fungi. Dev. Comp. Immunol. 2010, 34, 1129-1136. [CrossRef] [PubMed]

63. Turrà, D.; Segorbe, D.; Pietro, A.D. Protein kinases in plant-pathogenic fungi: Conserved regulators of infection. Annu. Rev. Phytopathol. 2014, 52, 267-288. [CrossRef] [PubMed]

64. Lieb, B.; Ebner, B.; Kayser, H. Cdna sequences of two arylphorin subunits of an insect biliprotein: Phylogenetic differences and gene duplications during evolution of hexamerins-implications for hexamer formation. J. Exp. Zool. Part B 2016, 326, 136-148. [CrossRef] [PubMed]

65. Park, S.Y.; Kim, C.H.; Jeong, W.H.; Lee, J.H.; Seo, S.J.; Han, Y.S.; Lee, I.H. Effects of two hemolymph proteins on humoral defense reactions in the wax moth, Galleria mellonella. Dev. Comp. Immunol. 2005, 29, 43-51. [CrossRef] [PubMed]

66. Martins, J.R.; Bitondi, M.M. Nuclear immunolocalization of hexamerins in the fat body of metamorphosing honey bees. Insects 2012, 3, 1039-1055. [CrossRef] [PubMed]

67. Seitz, V.; Clermont, A.; Wedde, M.; Hummel, M.; Vilcinskas, A.; Schlatterer, K.; Podsiadlowski, L. Identification of immunorelevant genes from greater wax moth (Galleria mellonella) by a subtractive hybridization approach. Dev. Comp. Immunol. 2003, 27, 207-215. [CrossRef]

68. Ciencialova, A.; Neubauerova, T.; Sanda, M.; Sindelka, R.; Cvacka, J.; Voburka, Z.; Budesinsky, M.; Kasicka, V.; Sazelova, P.; Solinova, V.; et al. Mapping the peptide and protein immune response in the larvae of the fleshfly Sarcophaga bullata. J. Pept. Sci. 2008, 14, 670-682. [CrossRef] [PubMed]

69. Kim, C.H.; Shin, Y.P.; Noh, M.Y.; Jo, Y.H.; Han, Y.S.; Seong, Y.S.; Lee, I.H. An insect multiligand recognition protein functions as an opsonin for the phagocytosis of microorganisms. J. Biol. Chem 2010, 285, 25243-25250. [CrossRef] [PubMed]

70. Zhao, L.; Kanost, M.R. In search of a function for hemolin, a hemolymph protein from the immunoglobulin superfamily. J. Insect Physiol. 1996, 42, 73-79. [CrossRef]

71. Lanz-Mendoza, H.; Bettencourt, R.; Fabbri, M.; Faye, I. Regulation of the insect immune response: The effect of hemolin on cellular immune mechanisms. Cell Immunol. 1996, 169, 47-54. [CrossRef] [PubMed]

72. Yu, X.Q.; Zhu, Y.F.; Ma, C.; Fabrick, J.A.; Kanost, M.R. Pattern recognition proteins in Manduca sexta plasma. Insect Biochem. Mol. Biol. 2002, 32, 1287-1293. [CrossRef]

73. Sotelo-Mundo, R.R.; Lopez-Zavala, A.A.; Garcia-Orozco, K.D.; Arvizu-Flores, A.A.; Velazquez-Contreras, E.F.; Valenzuela-Soto, E.M.; Rojo-Dominguez, A.; Kanost, M.R. The lysozyme from insect (Manduca sexta) is a cold-adapted enzyme. Protein Pept. Lett. 2007, 14, 774-778. [CrossRef] [PubMed]

74. Li, B.; Paskewitz, S.M. A role for lysozyme in melanization of sephadex beads in Anopheles gambiae. J. Insect Physiol. 2006, 52, 936-942. [CrossRef] [PubMed] 
75. Fauvarque, M.O.; Williams, M.J. Drosophila cellular immunity: A story of migration and adhesion. J. Cell Sci. 2011, 124, 1373-1382. [CrossRef] [PubMed]

76. Kuruvilla, S.; Jacob, A. Host range of the entomogenous fungus Fusarium oxysporum Schlecht and its safety to three crop plants. Curr. Sci. 1979, 48, 603.

77. Morquer, R.; Nysterakis, F. Rôle des fusariées entomophytes comme destructeurs d'insectes. Bull. Soc. Hist. Nat. Toulouse 1944, 79, 281-318.

78. Kilpatrick, R.A. Fungi associated with larvae of Sitona spp. Phytopathology 1961, 51, 640-641.

79. Di Pietro, A.; García-Maceira, F.I.; Méglecz, E.; Roncero, M.I.G. A MAP Kinase of the vascular wilt fungus Fusarium oxysporum is essential for root penetration and pathogenesis. Mol. Microbiol. 2001, 39, 1140-1152. [CrossRef] [PubMed]

80. Delgado-Jarana, J.; Martínez-Rocha, A.L.; Roldán-Rodriguez, R.; Roncero, M.I.G.; Pietro, A.D. Fusarium oxysporum g-protein $\beta$ subunit fgb1 regulates hyphal growth, development, and virulence through multiple signalling pathways. Fungal Genet. Biol. 2005, 42, 61-72. [CrossRef] [PubMed]

81. Caracuel, Z.; Martínez-Rocha, A.L.; Di Pietro, A.; Madrid, M.P.; Roncero, M.I.G. Fusarium oxysporum gas1 encodes a putative $\beta$-1,3-glucanosyltransferase required for virulence on tomato plants. Mol. Plant Microbe Interact. 2005, 18, 1140-1147. [CrossRef] [PubMed]

(C) 2018 by the authors. Licensee MDPI, Basel, Switzerland. This article is an open access article distributed under the terms and conditions of the Creative Commons Attribution (CC BY) license (http:/ / creativecommons.org/licenses/by/4.0/). 